\title{
TOWARDS MORE ENVIRONMENTALLY SUSTAINABLE INTERCONTINENTAL FREIGHT TRANSPORT
}

\author{
FRANS BAL ${ }^{1} \& \mathrm{JAAP}$ VLEUGEL ${ }^{2}$ \\ ${ }^{1}$ University of Applied Sciences, The Netherlands \\ ${ }^{2}$ Delft University of Technology, The Netherlands
}

\begin{abstract}
In a world where the population and many economies are expanding rapidly the demand for freight transport keeps rising accordingly. As more goods are transported by a growing number of freight vehicles, in particular trucks and sea vessels, their already considerable negative environmental impact also rises. Technology advances, but demand growth (partially) counteracts its positive impact on fuel consumption and emissions. In road transport, $\mathrm{CO}_{2}$-emissions keep rising, while emissions of $\mathrm{NO}_{\mathrm{x}}$ and $\mathrm{PM}_{10}$ have been reduced, at least in those countries where the most advanced engine technologies are used, although locally serious problems may remain. In areas where such technologies are not available, more freight transport means higher emissions and negative health effects. Sea shipping sees increasing emission levels overall. Maritime transport and trucking dominate intercontinental freight transport. Modernisation of railways and roads offers opportunities to reduce emissions by using rail for part of the journey. In a market setting, this means that transport providers have to redesign transport chains. Some have done this already, while others are increasingly interested. To assess the potential, the following main research question was addressed: Is it possible to reduce emissions of $\mathrm{CO}_{2}, \mathrm{NO}_{\mathrm{x}}$ and $\mathrm{PM}_{10}$ by replacing the maritime leg of a transport service by road and/or rail transport in the corridor Antwerp (Belgium) - Shanghai (China) without logistic penalties? Various combinations of trucking, sea and rail transport were fed into a simulation model to estimate the accompanying emissions and trip times. The new services offer a complex range of positive and negative impacts; hence governments should carefully consider their support. In a simulation study only a very stylised representation of these services can be modelled. This leads to an advice for a more in-depth study to include additional (technical, service and cost) data.

Keywords: Intercontinental freight transport, fuel consumption, emissions, trip time, simulation, evaluation.
\end{abstract}

\section{INTRODUCTION}

Economic development is not evenly spread around the globe, on the contrary. Many SouthEast Asian economies grow very fast [1] because of a growing population, rise of the middle class (accelerating consumption and production). They house the world's major producers of goods, which are strongly supported by government. There are also countries with a stagnating or declining population and (related) structural economic and political challenges, yet most of their citizens (still) enjoy a high standard of living compared to the rest of the world. The European Union has many of such member states [2].

\section{Intercontinental freight transport}

The geographical distance between (final) production and (final) consumption of goods means that massive amounts of goods are traded and transported around the globe. Maritime transportation is dominant [3]. Countries separated by large water masses (oceans, seas) heavily rely on sea shipping as main carrier. Ocean shipping takes place with container ships circulating along sea routes, calling at several very large ports. Port calls take at least a day for (un)loading. Sea routes are long, while the weather adds logistic uncertainty. Currently a container vessel may take up to six weeks to sail between a port located at China's east 
coast to a port in Western Europe, a route of up to 20,000 km [4]. Trucks, trains and barges are used to transport smaller volumes. Trucks are usually necessary for the first and final leg of a multimodal transport service. The actual choice of main transport mode(s) may differ because of local conditions, such as (access to) ports, available land and sea routes, logistic parameters (time, cost, volumes) and preferences of the logistic partners involved. Containers have become a very popular loading unit due to their standard sizes, their protective and efficient (multimodal) handling capabilities [5].

\section{Eurasian countries}

This paper will focus on Eurasia, a very large landmass with The European Union in the west and China and the Russian Federation in the east. Transport over very long distances between east and west can take place over land, but it is complex, due to the administrative, political and infrastructure-technical differences between them. The quality of the infrastructure networks and services may also differ substantially. Such conditions hold in particular in rail transport, but roads may also differ locally. The terrain may present challenges, as many of these countries have mountain areas. Sometimes infrastructure networks are not directly connected or partially non-existent, as is the case with barge transport.

Governmental infrastructure policies have led to substantial improvements in Eurasia. In Europe, the Trans-European Networks (TEN) initiative is well underway. Its projects are financed by the EU and/or European investment banks. Works are undertaken by local or European construction companies [6]. In China, the government is developing inland infrastructures (rail, road, inland waterways and (air)ports) at an impressive pace. One of the aims is to spread economic development more evenly. Especially its western part could reap economic benefits from improved infrastructure. Many other Asian countries are also improving their infrastructure. Infrastructure connected with China is also known as Belt \& Road Initiatives (BRI) or New Silk Route(s) (NSR). Chinese state-owned banks and rail and road construction companies are involved in projects to renovate existing and build new infrastructure corridors outside China. A budget of 1 trillion USD was connected with the BRI, which is presented as a global design with attention for hard and soft infrastructures. Most of the construction work is carried out by Chinese companies, hence the first order benefits befall the Chinese partners. The countries passed may receive second order (more durable) economic benefits from the new infrastructure and trade routes in terms of local employment, tax income and higher economic growth, at least that is how these projects are presented [7]. Substantial loans are given to less developed countries, which creates a financial and political dependency, especially given the high interest rates and related default risk. The financial support by the Chinese government primarily seems to serve its own economic and political agenda [8]. The dependency of Eurasian countries on China's already dominant industries will become even stronger, which is likely to have profound geo-political implications, especially at a time when the US' government has a rather different perspective on foreign (economic and political) relations than its predecessors [9].

In EU countries strict economic planning is a thing of the past. This contrasts especially with China's 5-year plans as part of a longer-term development agenda [10].

Effective and efficient overland connections between China and Europe may eventually create a partial shift from maritime (or air) to overland transport. The volume of containers transported between Europe and China was about $15 \mathrm{mln}$ in 2017. Railways carried 200,000 TEU [11]. With double digit yearly growth figures, the 1 mln TEU mark will soon be reached. A total of 663 freight train trips was made between Chongqing and Europe in the same year [12]. 


\section{Externalities}

Freight transport also creates considerable negative externalities; damage from infrastructure construction (destruction and dissection of landscapes) and transport services (climate change, air pollution, noise, traffic accidents, congestion) [13].

The aim of this paper is to study how new long distance overland freight services could perform in terms of emissions and logistics. This goes along with the following main research question: Is it possible to reduce emissions of $\mathrm{CO}_{2}, \mathrm{NO}_{\mathrm{x}}$ and $\mathrm{PM}_{10}$ by replacing the maritime leg of a transport service by road and/or rail transport in the corridor Antwerp (Belgium) Shanghai (China) without logistic penalties?

The following sub-questions are used to answer this main question:

Q1: What are the best routes to transport freight between Antwerp and Shanghai?

Q2: How could a (combined) transport service for these routes look like?

Q3: What are the $\mathrm{CO}_{2}^{-}, \mathrm{NO}_{\mathrm{x}}-$ and $\mathrm{PM}_{10}$-emissions related with such a service?

Q4: Does a reduction of these emissions warrant support by respective governments of the involved countries to further the development of the NSR and related infrastructure?

Q5: What are the broader logistic and traffic implications of a shift from sea to overland transport?

\section{METHODOLOGY}

Several methodological choices were made due to practical reasons. The focus is on freight services on the Europe-Russian Federation-China axis. Modes considered were sea, road and rail. Externalities considered are the contribution to climate change (by $\mathrm{CO}_{2}$ emissions) and local air pollution $\left(\mathrm{NO}_{\mathrm{x}}\right.$ and $\left.\mathrm{PM}_{10}\right)$, as far as the available public data allow. The time horizon is the year 2025 to allow ongoing improvements of infrastructure and services.

The following steps were taken to reach the main aim of the paper:

- Choose the most relevant transport corridors to coincide as close as possible with the ones frequently mentioned in scientific and professional literature. Those in the eastern part of Eurasia include branches of the New Silk Route (NSR). Missing data about vehicles, routes and services was filled in by assumptions, as will be further explained in Section 3.

- Modify the existing scenario simulation model to include the studied routes/services, add transport modes and fuels as well as emission parameters for $\mathrm{CO}_{2^{-}}, \mathrm{NO}_{\mathrm{x}}-$ and $\mathrm{PM}_{10}$.

- Run the simulation model with the chosen routes and modalities in order to estimate fuel consumption, emissions and trip time.

- Evaluate the simulation results quantitatively.

- Finally, write policy recommendations based on this evaluation.

A MS( $\odot$ Excel@ model was used estimate the energy consumption and emissions of the chosen freight transport modes in the chosen corridors. Fuel consumption is an average based on the estimated km 'driven' via a specific one-way route. Emissions are based on this estimated fuel consumption and emission factors for each fuel. The model consists of:

- a data entry and calibration module allowing changes in user data, e.g. transport means, fuels and infrastructure (section) length;

- matrices with data about fuel consumption, emission factors (ef) and tank-to-wheel (ttw) emissions. 
- a choice box to estimate the emissions of different source mixes to produce electricity;

- a solver module with policy scenarios as constraints to the linear programming.

\section{SCENARIOS}

\subsection{Introduction}

The scenarios help to estimate the fuel consumption, emissions per container (TEU) and trip time for alternative transport services and routes. Relevant logistic and traffic impacts will be mentioned as far as data allows.

The reference case would be using a conventional container vessel. The sea link from China's east coast takes about 36 days (6 weeks) [14]. Overland alternatives are trucking only and rail (with pre-haulage by road). Part of the service could also be carried out by short sea services (ferries). Because of practical reasons, air transport and short sea are not considered in the scenarios.

\subsection{The New Eurasia Land Bridge (corridor)}

This corridor is also known as initiative BRI6 among the proposed Belt and Road Initiatives by the Chinese (national) government [15]. The dotted lines in Figure 1 refer to the current sea routes. The rather straight overland route is obviously much shorter than the sea route.

In theory, many origin and destination hubs (in ports) could have been chosen for this study. To simplify matters, Chongqing Guoyuan Port was chosen as origin in south-east China. This city has a free trade port area along the Yangtze river and an integrated international airport [16]. Antwerp Port in Belgium, Europe's second largest port, is the final destination.

Ideally, technical information (actual vehicles used and local condition of infrastructure and services, electric power generation) would be freely available. Many parties are involved in freight transport, which is not a public service. Economic and other reasons prevent stakeholders from sharing (technical) information. Sources of information also contradict each other. As a way out, a decision was made to standardise on a certain known vehicle class and then assume that all services would use this vehicle, either truck, train, vessel or combination.

Figure 2 gives an example of the alternative rail corridors (north, centre and south), which are about $12,000 \mathrm{~km}$ in length.

\subsection{Scenario A: Sea + rail}

Chongqing as an inland hub needs inland transport to a nearby port. There is the east connection via Shanghai $(1,443 \mathrm{~km})$. An alternative is to use the Southern Chongqing-ASEAN Highway Shuttle Corridor $(5,060 \mathrm{~km})$.

\subsubsection{Alternative 1: To Shanghai by train and then by sea}

A choice was made to standardise on a widely used locomotive type, the Siemens Vectron, as information about actually used Chinese locomotives is missing. The Vectron is available with electric and diesel engines and used (on corridor sections) in countries like Germany, Austria and Hungary. Its technology is also deployed in China. One may assume that China's main railway lines are electrified, which allows the use of the (most powerful) electric Vectron 


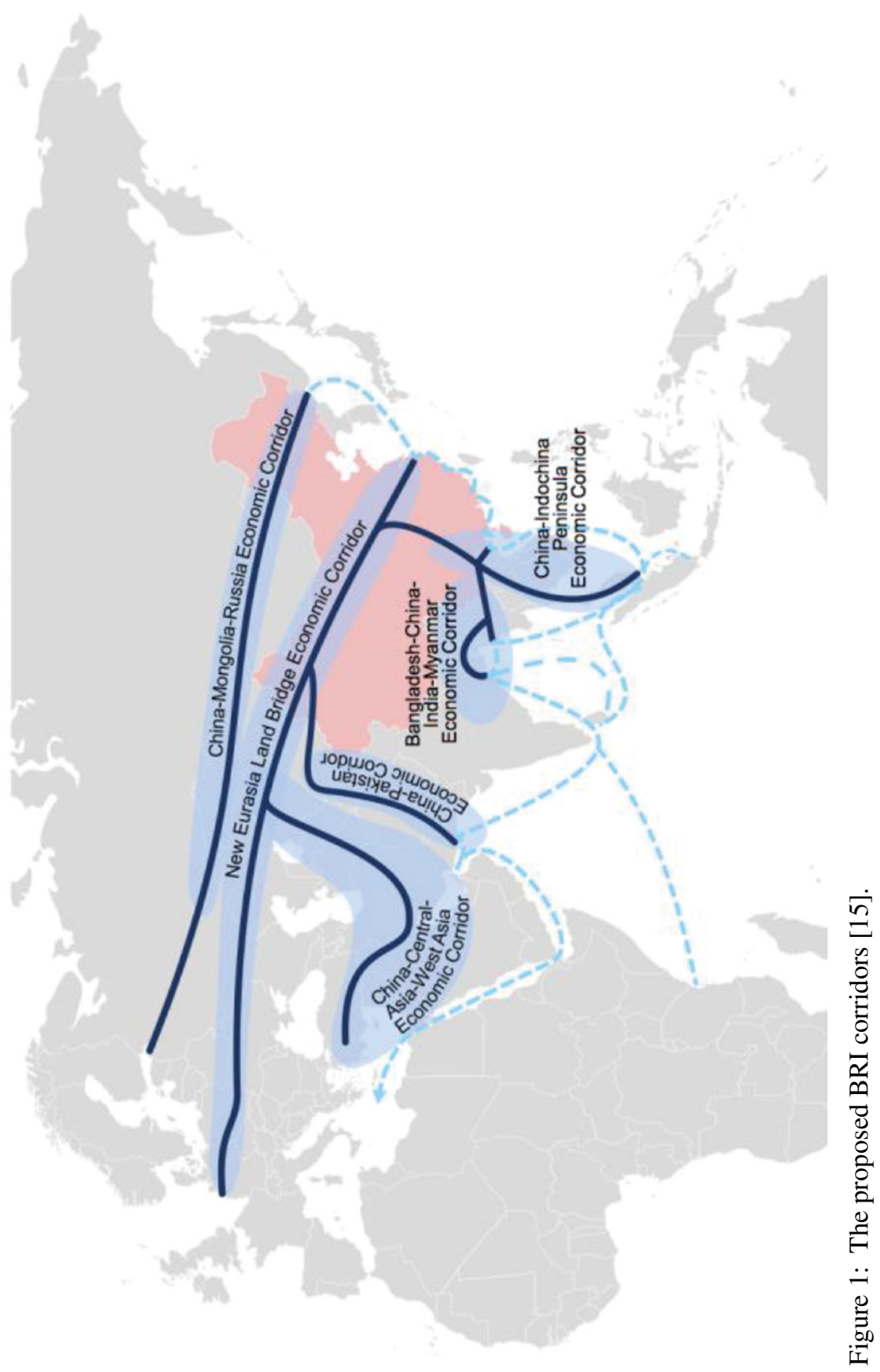




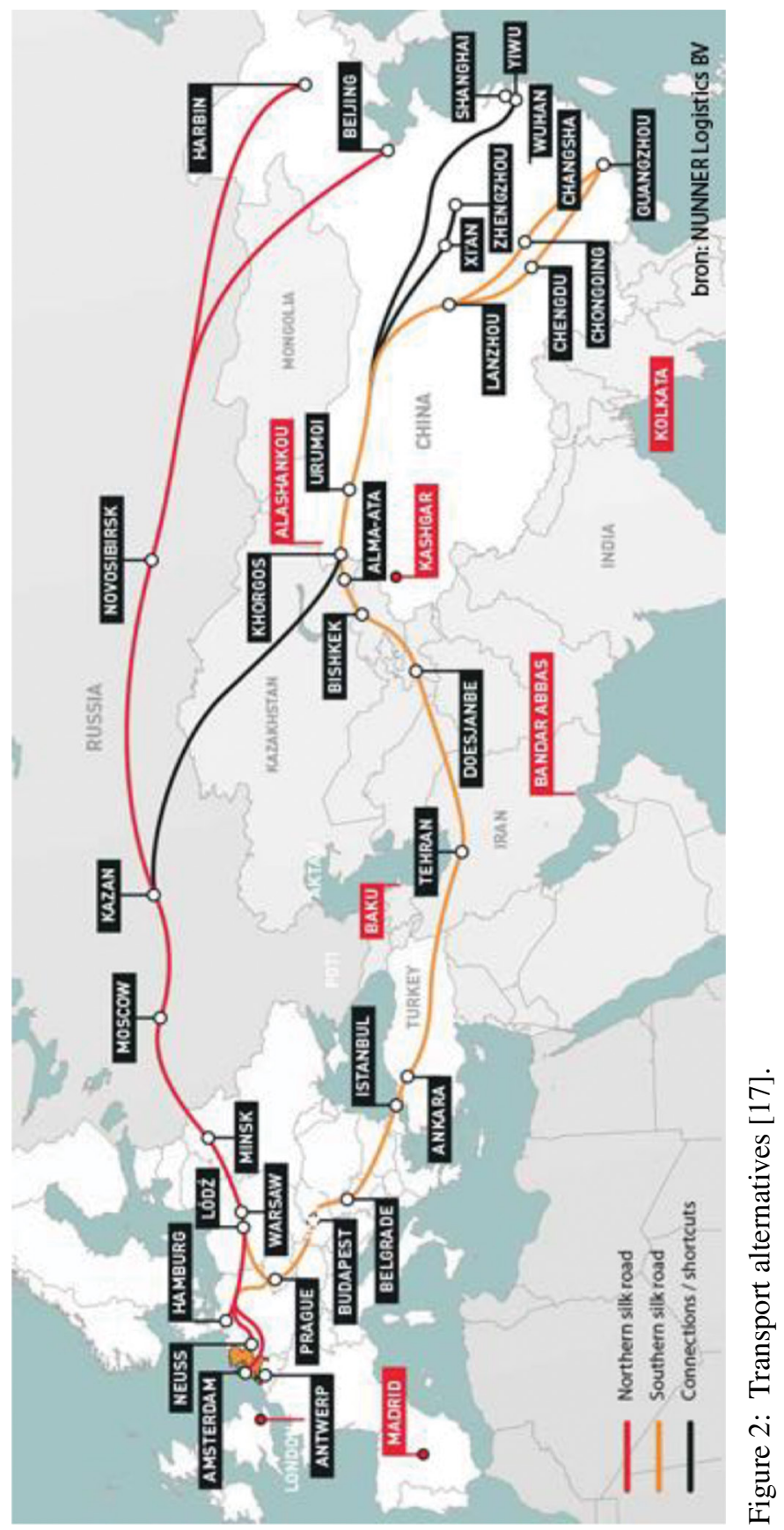


locomotive. One locomotive should have sufficient tractive force to pull a container train of up to 84 TEU (container equivalent) [18].

Table 1 contains the estimated electric power use of a Vectron locomotive and related $\mathrm{CO}_{2}$ emissions. Since the actual grid mix varies during the trip between nuclear, fossil, hydro or wind power, emissions of $\mathrm{NO}_{\mathrm{x}}$ and $\mathrm{PM}_{10}$ could not be estimated.

It was assumed that a container ship of about 10,000 TEU was deployed, sailing with an average speed of $18 \mathrm{knots} / \mathrm{hour}(44,45 \mathrm{~km} / \mathrm{h})$. This is the most economical way of steaming that still matches the demand of the market.

This implies an average fuel consumption of 100 tons per day. A ship sailing 24 hours per day will then cover a distance of around $1,067 \mathrm{~km}$ per day. During a 24 day trip towards Antwerp its main engines burn about 2,457 tons of HFO. All figures are averages, weather conditions are assumed to be randomly distributed and locomotive and crew changes are assumed to not take additional time.

A simplification was to skip the impact of port calls and sail on HFO only, opposite to [19], which considers the use of MGO/MDO during calls as various countries no longer allow HFO use in their littoral waters.

The vessel carries 10,000 TEU during the whole voyage, regardless of the (un)loading cycle in intermediate ports, which complies with an economically optimal use of the vessel. Table 2 contains the vessel's emissions. Changing fuel source (in multi-fuel engines) affects emissions. Shore power is hardly available. Both would reduce emissions compared to a complete voyage undertaken with HFO [19]. This means that the estimates presented in Tables 2 may overestimate the actual emissions if these cleaner sources would be used and their impact on emissions would be monitored effectively. Emissions from transhipment operations in terminals are excluded as was done in the alternative trip scenarios.

Table 1: Estimated emissions of a train service between Chongqing and Shanghai. (Own estimations).

\begin{tabular}{lcccc}
\hline \multicolumn{5}{c}{ Estimated emissions in $\mathrm{kg}$} \\
\cline { 2 - 5 } For & Average electric power use $(\mathrm{kWh})$ & $\mathrm{CO}_{2}$ & $\mathrm{NO}_{\mathrm{x}}$ & $\mathrm{PM}_{10}$ \\
\hline $84 \mathrm{TEU}$ & 217 & 211 & - & - \\
$1 \mathrm{TEU}$ & 2.6 & 2.5 & - & - \\
\hline
\end{tabular}

Table 2: Estimated emissions of a container vessel's main engines. (Own estimations).

\begin{tabular}{lccc}
\hline & \multicolumn{3}{c}{ HFO: Estimated emissions in $\mathrm{kg}$ (HFO only) } \\
\cline { 2 - 4 } For & $\mathrm{CO}_{2}$ & $\mathrm{NO}_{\mathrm{x}}$ & $\mathrm{PM}_{10}$ \\
\hline 10.000 TEU & $6,230,798$ & 133,660 & 6,140 \\
84 TEU & 52,339 & 1,123 & 52 \\
1 TEU & 623 & 13.4 & 0.61 \\
\hline
\end{tabular}


Combining rail in China and the sea trip gives Table 3.

Table 3: Estimated emissions from the full trip Chongqing-Shanghai-Antwerp. (Own estimations).

\begin{tabular}{lccl}
\hline & \multicolumn{3}{c}{ Estimated emissions in kg (HFO + electricity) } \\
\cline { 2 - 4 } For & $\mathrm{CO}_{2}$ & $\mathrm{NO}_{\mathrm{x}}$ & $\mathrm{PM}_{10}$ \\
\hline $84 \mathrm{TEU}$ & 52.55 & $\geq 1,123$ & $\geq 52$ \\
$1 \mathrm{TEU}$ & 626 & $\geq 13.4$ & $\geq 0.614$ \\
\hline
\end{tabular}

\subsubsection{Alternative 2: To Singapore by train}

An important logistic reason to develop a southern link [20] (Table 4) from Chongqing to the port of Singapore was to prevent the loss of time (up to a month) connected with sending goods east by train or truck and then let a container vessel sail additional $\mathrm{km}$. Congestion in Shanghai's port is already considerable. More trains would worsen the situation.

Table 4: Detailed train emissions Chongqing-Singapore (Own estimations based on [21].)

\begin{tabular}{llccc}
\hline Rail section & Country & $\mathrm{kWh}$-used & $\begin{array}{r}\mathrm{CO}_{2} \mathrm{EF}^{*} \\
(\mathrm{~kg} / \mathrm{kWh})\end{array}$ & $\mathrm{CO}_{2}(\mathrm{~kg})$ \\
\hline Chongqing-Mohan (Boten) & China & 218 & 0.97 & 213 \\
Mohan (Boten)-Vientiane & Laos & 64 & 0.8 & 51 \\
Vientiane-Pedang Besar & Thailand & 266 & 0.63 & 167 \\
$\begin{array}{l}\text { Pedang Besar-Singapore } \\
\text { (Woodlands) }\end{array}$ & Malaysia & 211 & 0.75 & 158 \\
$\begin{array}{l}\text { Singapore (Woodslands) }- \\
\text { Singapore port }\end{array}$ & Singapore & 1 & 0.58 & 0.6 \\
Total per 84 TEU & & 760 & & 422.6 \\
\hline
\end{tabular}

This alternative is known as the Chongqing-ASEAN Highway Shuttle [19]. A train reaches Singapore after a trip of 5,060 km, passing several South-East Asian countries, which are therefor also integrated into this BRI initiative. It is assumed that electric locomotives would be used. Table 5 contains the generated emissions of $\mathrm{CO}_{2}$.

Table 5: Estimated electric train emissions Chongqing-Singapore (Own estimations).

\begin{tabular}{lccc}
\hline \multirow{2}{*}{ For } & \multicolumn{3}{c}{ Estimated emissions in kg (Electricity only) } \\
\cline { 2 - 4 } & $\mathrm{CO}_{2}$ & $\mathrm{NO}_{\mathrm{x}}$ & $\mathrm{PM}_{10}$ \\
\hline $84 \mathrm{TEU}$ & 423 & - & - \\
$1 \mathrm{TEU}$ & 5 & - & - \\
\hline
\end{tabular}

The estimated emissions from sailing from Port of Singapore via Port of Colombo to Port of Antwerp can be found in Table 6. 
Table 6: Estimated emissions of a container vessel's main engines. (Own estimations).

\begin{tabular}{lrrr}
\hline & \multicolumn{3}{c}{ HFO: Estimated emissions in $\mathrm{kg}$ (HFO only) } \\
\cline { 2 - 4 } For & $\mathrm{CO}_{2}$ & $\mathrm{NO}_{\mathrm{x}}$ & $\mathrm{PM}_{10}$ \\
\hline 10.000 TEU & $4,818,753$ & 103,368 & 4,750 \\
84 TEU & 40,478 & 868 & 40 \\
1 TEU & 482 & 10.3 & 475 \\
\hline
\end{tabular}

Combining rail in South-east Asia and the sea trip from Singapore gives Table 7.

Table 7: Estimated emissions from a trip Chongqing-Singapore-Antwerp. (Own estimations).

\begin{tabular}{lccc}
\hline & \multicolumn{3}{c}{ Estimated emissions in $\mathrm{kg}(\mathrm{HFO}+$ electricity + diesel $)$} \\
\cline { 2 - 4 } For ${ }^{1)}$ & $\mathrm{CO}_{2}$ & $\mathrm{NO}_{\mathrm{x}}$ & $\mathrm{PM}_{10}$ \\
\hline 84 TEU & 40,901 & 868 & 40 \\
1 TEU & 487 & 10.33 & 0.48 \\
\hline
\end{tabular}

Note: (1) For comparison with Table 7, the 10,000 TEU values are left out.

\subsection{Scenario B: Rail only}

It was assumed that rail was used for the whole trip. Pre-haulage by truck to a rail terminal (port) and its emissions was not considered because of lack of local road maps and hence distances. Estimated $\mathrm{CO}_{2}$-emissions of electric traction can be found in Table 8 .

Table 8: Detailed train emissions Chongqing-Antwerp. (Own estimations).

\begin{tabular}{llccc}
\hline $\begin{array}{l}\text { Distance: } 11.179 \mathrm{~km} \\
\text { Trajectories }\end{array}$ & Country & $\mathrm{kWh}$-used & $\begin{array}{r}\mathrm{CO}_{2} \mathrm{EF}^{*} \\
(\mathrm{~kg} / \mathrm{kWh})\end{array}$ & $\mathrm{CO}_{2}(\mathrm{~kg})$ \\
\hline Chongqing-Khorgos & China & 588 & 0.97 & 573 \\
Khorgos-Troitsk & Kazakhstan & 228 & 0.92 & 211 \\
Troitsk-Orsha & Russian & 301 & 0.51 & 155 \\
& Federation & & & \\
Orsha-Brest & Belarus & 309 & 0.61 & 189 \\
Brest-Frankfurt (Oder) & Poland & 103 & 1.2 & 123 \\
Frankfurt (Oder)- & Germany & 94 & 0.67 & 63 \\
Mönchengladbach & & & & \\
Mönchengladbach-Antwerp & Belgium & 23 & 0.22 & 5 \\
Total (84 TEU) & & 1,646 & & 1,319 \\
Total (1 TEU) & & & & 16 \\
\hline
\end{tabular}

The lack of data about the grid mix in each region/country excludes an estimation of $\mathrm{NO}_{\mathrm{x}}$ and $\mathrm{PM}_{10}$-emissions. In reality, electric locomotives use 'green' electricity in Germany, but this is omitted due to the lack of data about the grid mix in the other countries. 
Another assumption is that switching between normal rail gauge $(1,435 \mathrm{~mm})$ and broad gauge (1,680 mm, mainly Russian Federation and Belarus) will be taken care of technically (by using flexible axes or trans loading) without a major time penalty or additional emissions. It is also assumed that the Russian Federation allows all goods categories to be shipped by train. Otherwise a detour of some $400 \mathrm{~km}$ would be needed for the excluded goods categories.

The important logistic hub at Khorgos (Kazakhstan), at the border with China is not electrified, hence diesel locomotives are needed. A Vectron Diesel can provide these services between Urumqi (China) and Astana (Kazakhstan). With an average emission of $207 \mathrm{~g} / \mathrm{kWh}$ of $\mathrm{CO} 2$, Table 9 shows the higher estimated emissions for the entire 11,179 km trip between Chongqing and the port of Antwerp, with a diesel service between Chongqing and Astana followed by electric traction to the Port of Antwerp.

Table 9: Estimated emissions from a trip Chongqing-Moscow-Antwerp. (Own estimations).

\begin{tabular}{lrrr}
\hline & \multicolumn{3}{c}{ Estimated emissions in $\mathrm{kg}$ (Electric and diesel traction) } \\
\cline { 2 - 4 } For ${ }^{1)}$ & $\mathrm{CO}_{2}$ & $\mathrm{NO}_{\mathrm{x}}$ & $\mathrm{PM}_{10}$ \\
\hline $84 \mathrm{TEU}$ & 5,155 & 21 & 5 \\
$1 \mathrm{TEU}$ & 61 & 0.25 & 0.06 \\
\hline
\end{tabular}

Note: (1) For comparison with Table 7, 10,000 TEU values are left out.

\subsection{Scenario C: Long-distance trucking}

At first, trucking the full distance seems rather farfetched for the entire 10,640 km. However, long distance trucking exists. A Dutch truck operator was the first to travel $6,437 \mathrm{~km}$ from Rotterdam via Moscow into Western China [22]. China has joined the T.I.R. convention to simplify and harmonise the administrative formalities of international road transport [23]. It also opened its Western border for foreign trucking companies. This will give a major boost to road transport to and from China.

Interesting is that the link E30/A2 from Moscow to Słubice (Poland) and further towards Berlin (Germany) runs almost parallel to the railway line. This makes a direct comparison between truck and train services possible.

Again some standardisation is applied. It is assumed that the whole trip is done with certified Euro 6 truck-trailer sets; the least polluting in Europe (Table 10). They can carry 2 TEU per trip. Approximately 3,400 liter of diesel is needed to complete a one-way trip.

Table 10: Estimated emissions from a trip Chongqing-Khorgos-Moscow-Antwerp. (Own estimations).

\begin{tabular}{lrrr}
\hline & \multicolumn{3}{c}{ Estimated emissions in $\mathrm{kg}$ (diesel truck) } \\
\cline { 2 - 4 } For & $\mathrm{CO}_{2}$ & $\mathrm{NO}_{\mathrm{x}}$ & $\mathrm{PM}_{10}$ \\
\hline $2 \mathrm{TEU}$ & 9,023 & 37 & 9 \\
$1 \mathrm{TEU}$ & 4,512 & 18.5 & 4.5 \\
$84 \mathrm{TEU}$ & 378,966 & 1,554 & 378 \\
\hline
\end{tabular}

Alternative fuels were not considered given the lack of dedicated 'green' trucks, their limited range and lack of charging network. 


\subsection{Comparison}

Table 11 compares the service and route alternatives. The estimated trip times are based on external sources. They depend on many factors, including technical, traffic conditions, legal and weather conditions and as such may vary considerably. Nonetheless, rail scores best in environmental performance. It is comparable to road in trip time. If pre- and end haulage (aspects of flexibility and accessibility) towards the train service would be included then the rail alternative emits more and the gap between rail and road would become smaller. But, this can be prevented if the 'diesel island' around Khorgos was electrified; an example of a relatively modest cross-border improvement [24] with clear environmental benefits.

Table 11: Comparison of scenario results Chongqing-Antwerp. (Own estimations).

\begin{tabular}{|c|c|c|c|c|c|c|}
\hline & \multicolumn{5}{|c|}{ Estimated $\mathrm{CO}_{2}$-emissions for $1 \mathrm{TEU}$ in $\mathrm{kg}$} & \multirow[t]{2}{*}{ Time (days) $[11 ; 22]$} \\
\hline & Rail (E) & Rail (D) & Sea & Truck & Total & \\
\hline Direct & 16 & 89 & & 4,512 & & $10-15$ \\
\hline Direct & \multicolumn{2}{|c|}{61} & & & & $10-15$ \\
\hline Shanghai & 2.6 & & 623 & & 625.6 & $35-55$ \\
\hline Singapore & & 28 & 487 & & 515 & $33-55$ \\
\hline Singapore & 5 & & 487 & & 492 & $33-55$ \\
\hline
\end{tabular}

Sailing via current routes takes 2-3 times longer than the overland alternatives. The logistic consequences of replacing a container ship are major (Table 12). The required additional number of land vehicles (and already scarce) drivers can be staggering. It is also a question whether rail and roads have the capacity reserves needed to serve a much larger number of vehicles. Many roads and mainlines in Western Europe already experience serious capacity bottlenecks.

Table 12: Comparison of load capacity Chongqing-Antwerp (Own estimations).

\begin{tabular}{lrc}
\hline & \multicolumn{2}{c}{ Shipping 10,000 TEU } \\
\cline { 2 - 3 } & Units & Penalties \\
\hline Container ship & 1 & \\
Trains & 119 & Time, congestion, organisation \\
Trucks & 5,000 & Time, congestion, organisation \\
\hline
\end{tabular}

Rail and road will be used more in future, but it is very unlikely that a real dent is made in the volume shipped by sea given the massive volumes transported.

\subsection{Evaluation}

It was a major challenge to (re)construct the various trip/route scenario's due to very limited public data. Almost all maps contain data about passenger services. Freight trains may often take different routes due to government regulations, geopolitics, infrastructure limitations, maintenance or reconstruction. References about existing rail freight service contradict each other in various ways, including basic data such as trip distances and nodes served by the train services. Western software such as Googlemaps is does not function in China. The 
electric power mix per rail leg is not known (in English), nor are the local performance characteristics of locomotives. Emission estimates are based on a set of consistent assumptions. The simulation model does not incorporate micro-details such as the impact of idling, variations in train length, load-density etc. on energy consumption and emissions [25], but is based on a given train length and average energy consumption data per train set (84 TEU; gross weight) as determined by the locomotive manufacturer after millions of railway miles. But, the estimates are a globally correct. They may help policy makers to better understand the real impact of the new service offerings.

\section{CONCLUSIONS}

The answer to the main research question is that a reduction of the emissions of $\mathrm{CO}_{2}$ is possible by replacing the maritime leg of a transport service by land transport. The estimations of $\mathrm{NO}_{\mathrm{x}}$ and $\mathrm{PM}_{10}$ should be used with some caution given the uncertainty surrounding the fuel sources of the electric power grid. Still, rail scores best given the assumptions used. It will score even better if all railways involved would use 'green' electricity as do currently the German (and Dutch) railways.

Railways do not necessarily need large investments in new infrastructure to become more competitive. Electrification of 'diesel islands' has logistic benefits and reduces emissions. Streamlining of (cross-border) operations by harmonised legislation (a BRI instrument) is again a crucial element. Shorter waiting times reduce idling of locomotive engines and lead to lower emissions.

If a container vessel would be replaced by a multitude of trains and trucks then considerable logistic and traffic implications may occur. Rail and road networks may need major expansion, especially in areas already suffering from congestion. Many more trucks, locomotives and wagons are needed, let alone a much higher number of already scarce drivers. But, congestion in port areas may be reduced. Sea shipping is under pressure to reduce its emissions, but this may take years to happen. Fuel consumption may be reduced by slow steaming, but this has a logistic penalty, because it doubles the voyage times.

As the new services offer such a complex range of positive and negative impacts, governments should carefully consider support for the new rail and road alternatives offered by the NSR.

\section{REFERENCES}

[1] Asian Development Bank. Expanding economies in Asia deliver 60\% of global growth, https://www.adb.org/news/expanding-economies-asia-deliver-60-global-growth-adb (accessed 6 April 2017).

[2] Copelovitch, M., Frieden, J. \& Walter, S., The political economy of the Euro Crisis, https:// scholar.harvard.edu/files/jfrieden/files/friedencopelovitchwalter_cpsforthcoming.pdf, 2016.

[3] Schäfer, K., Söding, E. \& Zeller, M., Living with the oceans. A report on the state of the world's oceans. Maribus: Hamburg, 2010.

[4] Noack, R., Climate change cuts the shipping route between China and Europe by 5,000 miles, www.washingtonpost.com/world/2018/08/24/climate-change-cuts-shipping-route between-china-europe-by-miles (accessed 24 August 2018).

[5] An., Advantages of using containers, www://howtoexportimport.com/ADVANTAGESOF-USING-CONTAINERS-491.aspx (4 January 2019).

[6] European Commission, Infrastructure and Investment, www://ec.europa.eu/transport/ themes/infrastructure_en (7 January 2020).

[7] China UN, The Silk Road - From past to the future, www.china-un.org/eng/gyzg/ t1134206.htm (04 March 2014). 
[8] Kuo, L. \& Kommenda, N., What is China's Belt and Road Initiative?, www. theguardian.com/cities/ng-interactive/2018/jul/30/what-china-belt-road-initiative-silkroad-explainer (accessed 07 January 2020).

[9] Petersen, Th., US economic isolation hurts the global economy - and itself, www. bertelsmann-stiftung.de/en/topics/latest-news/2017/september/us-economic-isolationhurts-the-global-economy-and-the-us-itself (accessed 12 September 2017). South, N., The new Silk route on rails, http.thesaker.is/the-new-silk-route-on-rails (accessed 06 October 2018).

[10] China UN, China's 13th Five-year Plan, www.china-un.org/eng/zt/China123456 (accessed 07 January 2020).

[11] ING, Nieuwe Zijderoute - De gulden middenweg Sneller dan zeevervoer, goedkoper dan luchtvervoer, ING Economisch Bureau, ING, Amsterdam, November 2018.

[12] Mengjie, 663 freight train trips made between Chongqing, Europe, www.xinhuanet. com/english/2018-01/09/c_136882928.htm (01 September 2018).

[13] Rodrigue, J.P., The Geography of Transport Systems, 5th ed., ch. 4, 2020.

[14] Chang, A., Antwerp-Chongqqing direct rail freight link launched, /www.industry leadersmagazine.com/antwerp-chongqing-direct-rail-freight-link-launched/ (accessed 12 May 2011).

[15] Tilman, H., UN Presentation - Analysis of 6 projects along the BRI, www.unece.org/ fileadmin/DAM/ceci/documents/2019/PPP/Forum/Presentations/Session_4-Henry_ Tillman.PDF2019.

[16] CARS, China-Chongqing, www://railwaysuppliers.ca/members/exporting/prioritymarket-overview/china-chongqing.html, 2018.

[17] An., Trein China-Nederland, www.dand.nl/trein-china-nederland, D\&D Production and Sourcing/Runner Logistics B.V. (accessed 04 February 2020).

[18] MRCE, Siemens Vectron, www.mrce.eu/en/siemens-vectron, 2020.

[19] Bal, F., \& Vleugel, J.M. (2015) Container ship calls: Triple throughput without an increase in marine $\mathrm{CO}_{2}, \mathrm{NO}_{x}$ and $\mathrm{PM}_{10}$ emissions?, European Transport Trasporti Europei 2015, 58(25/26). pp. 1-17, 2015.

[20] China's People's Daily, China-Singapore Chongqing connectivity initiative 'Southern Transport Corridor; Rail and Sea Networks going global, www://wisenetasia.com/ china-singapore-chongqing-connectivity-initiative-southern-transport-corridor-railand-sea-networks-going-global.

[21] Ecometrica, The definitive emission factor database, Electric-specific Emission Factors for Grid Electricity, www.Emissionfactors.com. The emission factors (ef) of China and Thailand were added up and then divided by 2 get those for Laos.

[22] Dunn, K., On the 'New Silk Road,' a Father-Son Road Trip Goes 8,000 Miles to China and Back, Fortune/www://finance.yahoo.com/news/silk-road-father-son-road-103011681. html (accessed 2 June 2019).

[23] Leijen, M. van, The much debated truck vs train question resolved, www.railfreight.com/ specials/2019/10/15/the-much-debated-truck-vs-train-question-resolved/?gdpr=accept (accessed 15 October 2019).

[24] Vleugel, J.M. \& Bal, F., Some approaches to reduce transport time of intermodal services: Smart rail investments, European Transport - Trasporti Europei, 52(3), p. 1-15, 2013.

[25] Ligterink, N.E., Smit, T. \& Spreen, J.S., Insight in the energy consumption, $\mathrm{CO}_{2}-$ emissions and $\mathrm{NO}_{\mathrm{x}}$-emissions of rail freight transport, TNO and Connekt, TNO 2017R11679V2, April 2018. 